\title{
. \\ IJCRR \\ Section: Healthcare \\ A Cross-Sectional Study to Assess the Quality of life, Depression, Anxiety and Stress Levels after 45 Days COVID-19 Lockdown
}

Sci. Journal Impact

Factor: 6.1 (2018)

ICV: 90.90 (2018)

(c) (i) (3)

Copyright@IJCRR

\author{
Kashif Ali' ${ }^{1}$, Umamah Mufti ${ }^{2}$, Gaurav Sharma ${ }^{3}$, Aliya Mufti ${ }^{4}$ \\ 'Assistant Professor, Department of Physiology, Jamia Millia Islamia University, New Delhi, India; ${ }^{2}$ Research Scholar, Department of Envi- \\ ronmental Sciences, Amity University, Noida, UP, India; ${ }^{3}$ Assistant Professor, Neurophysiology, IMS-Banaras Hindu University, Varanasi, \\ UP, India; ${ }^{S}$ Senior Research Fellow, Department of Physiology, AllMS, New Delhi, India.
}

\section{ABSTRACT}

Rationale: The COVID-19 or the coronavirus is a highly contagious viral disease which spread from humans to humans through small droplets via Nose, Mouth, Cough, or exhales infected more than 3.76 million peopleacross 185 countries.

Objective: We aim to assess the Quality of life, depression, anxiety, stress levels in the Indian population due to COVID-19 and to find out the demographic groups which need more attention for the prevention of mental illness.

Methods: Participants were recruited through proliferative approach with aid of social media platforms and an online survey was conducted to assess knowledge about covid-19, Quality of life (WHQOL), Depression, Anxiety and Stress Scale (DASS-21). Statistical analysis by SPSS-2 was done and unpaired t-test was used to analyse the influence of lockdown on quality of life, depression and anxiety in the participants.

Results: 847 participants filled the questionnaire $64.1 \%$ participants have some knowledge and $35.9 \%$ have full knowledge about COVID-19. We found a significant difference in the WHOQOL \& DASS-21 between the male and female participants $(p=0.0001)$ and age (18-39 years \& 40-64 years) $(p=0.0001)$. There was significant difference in the WHOQOL $(p=0.0002) \&$ DASS-21 $(p=0.0001)$ with education level (bachelors and above or without bachelors) and occupation (government job/ private job) WHOQOL $(p=0.0001)$ DASS-21(0.0001). There was no significant difference between the average monthly family income groups $(p>0.05)$. Participants of majority and other religious groups showed a significant difference in WHOQOL $(p=0.0001)$ and DASS-21 score $(p=0.0001)$.

Conclusion: The government should focus on encouraging people for stress-free lifestyle by taking care of their livelihood, daily needs and social messages focusing on family support. Necessary measures need to be taken to increase awareness about covid-19 prevention and removing misconception regarding the association of the disease with any community.

Key Words: Corona Virus, COVID-19, Pandemic, Mental Health, Psychological issues, Anxiety, Depression, Stress, Public health

\section{INTRODUCTION}

Novel Coronavirus was originated from the Wuhan city of china in late December 2019. It arises as a burden of inexplicable instance having Pneumonia like symptoms. It is formally called COVID-19 by the World Health Organization. ${ }^{1}$ It became pandemic affecting the globe, leading to a public health emergency. For the $21^{\text {st }}$ century, Infectious Diseases becomes the crucial warning across the sphere. ${ }^{2}$ In India,> 64 lakh confirmed cases and $>$ one lakh deaths allocated due to COVID-19 have occurred. It is a Pandemic creating an immense impact on Public health, Influences the Individual wellbeing and cognitive aspects. ${ }^{3,4}$ An extensive outbreak of contagious diseases like COVID-19 may be conjoined with behavioural aspects like Depression, Anxiety, Stress etc. ${ }^{5}$ Various studies have explained the burden of contagious disease outbreak, having an impact on people's behaviour or psychological aspects like SARS( Severe acute Respiratory Syndrome) in 2003 and in 2009 Novel Influenza A (H1N1) Epidemic. ${ }^{6-9}$ The occurrence of this widespread disease, distress the community with lots of behavioural and psychological issues. ${ }^{10}$ Studies have shown depression and Psychological issues leading to Post Traumatic Stress Disorder. ${ }^{11}$ Keeping this objective in mind we investigate the Quality of

\section{Corresponding Author:}

Aliya Mufti, Senior Research Fellow, Department of Physiology, AlIMS, New Delhi, India Email: aliyamuftiaiims@gmail.com

ISSN: 2231-2196 (Print)

Received: 13.06 .2020
ISSN: 0975-5241 (Online)

Revised: 24.08 .2020
Accepted: 17.10 .2020
Published: 24.11 .2020 
Life, Depression, Anxiety, Stress levels in the Indian Population to focus on the mental health due to the COVID-19 Pandemic after 45 days of lockdown.

\section{MATERIALS AND METHODS}

Participants: The COVID-19 outbreak was declared a public health emergency of international concern on $30^{\text {th }}$ January 2020, and officially India got the lockdown on 25th March 2020. We conducted this cross-sectional study after 45 days of lockdown. We have used the proliferative approach to circulate the Questionnaire online social media platforms via Whatsapp or Email to the friends and others to enlarge the sample size and select the participants on the bases of Inclusion and Exclusion criteria.

\section{Inclusion Criteria}

1. Willing to participate in the study and able to give Informed Consent.

2. Must be an Indian Citizen.

3. Age between 18 to 64 years.

4. Should be physically and mentally fit with no history of psychiatric illness or treatment.

5. Must be able to read and understand English or Hindi computer-based questionnaire.

6. Should have regular family monthly income before lockdown.

\section{Exclusion Criteria}

1. Unwilling to participate in the study or unable to give Informed Consent.

2. Age less than 18 years or more than 64 years.

3. History of any psychiatric treatment or illness.

4. Unable to read and understand English or Hindi computer-based questionnaire.

5. No regular family monthly Income.

6. History of any substance of abuse or alcohol etc.

7. Not an Indian citizen.

8. He /She already participated in any such study during the lockdown.

\section{Experimental parameters}

\section{Knowledge about Corona Virus OR COVID-19}

Five items were used to measure coronavirus knowledge.

1. Do you know that $56^{\circ} \mathrm{C}$ for $30 \mathrm{~min}$, diethyl ether, $75 \%$ ethanol, per-acetic acid, and other lipid solvents can effectively kill the virus?

2. COVID-19's incubation period is generally 2-14 days.

3. COVID-19 is mainly transmitted through respiratory droplets and can also be transmitted through contact with infected surfaces.

4. Knowledge about social distancing, Hand washing, use of Mask, and sanitization.
5. Do you know that psychological balance can improve the body's immunity?

Participants were given score $0 / 1$ based on their reply and the total score is interpreted as 1- they did not have full knowledge about COVID-19 to 5- they have full knowledge. ${ }^{12}$

\section{B. Quality of Life Assessment Scale-(WHOQOL) Scale}

The WHOQOL-BREF is a multi-dimensional concept that includes domains related to physical, mental, emotional, and social functioning. It has 4 domains with each domain consisting of multiple items. The four domains were

1. physical health domain (7 items)

2. psychological health domain (6 items)

3. social relationships domain (3 items)

4. environmental health domain (8 items)

The scale also has QOL (one item) and general health (one item $)^{13}$ Score for each of the above item can vary from 1 to 5 on a five-point ordinal scale. ${ }^{14,15}$

\section{Depression, Anxiety and Stress Scale- (DASS-} 21)

The DASS-21 is a set of three self-report scales designed to measure the emotional states of depression, anxiety, and stress. Each of the three DASS-21 scales contains 7 items, divided into subscales with similar content. ${ }^{16}$

\section{Data Analysias}

Statistical analysis and interpretation were done using SPSS version 20 and values were expressed in mean (M) and standard deviation (SD). Unpaired t-test was done for the comparison of two groups.

\section{RESULTS}

\section{Demographics}

847 Participants were enrolled in the study based on Inclusion and Exclusion criteria. 543 males (64.1\%) and $304 \mathrm{fe-}$ males (35.9\%) participated in the study, none of the participants preferred not to answer about gender. The mean age of the participant was 46 years and $71.6 \%$ participants held a bachelor degree or above. Participants were grouped as 1839 years participants who are young and leading an active lifestyle (446 participants) and 40-64 years (401 participants) with relatively more responsibilities, poor physical activity and chronic health problems. 495 participants (58.4\%) were self-employed or were in private jobs and 352 participants $(41.6 \%)$ were students or in government jobs (relatively under less stress for job security and livelihood). $43.1 \%$ of the participants had an average monthly family income of less than Rs 20,000 before lockdown and 56.9\% were earning $>$ Rs 20,000 monthly before the announcement of lockdown. 
$64.9 \%$ of the participant was from the religious majority and $35.1 \%$ were from other religious groups (Figure $1 \&$ Table $1)$.

Table 1: Demographic data of the Participants $(\mathbf{n}=$ 847)

\begin{tabular}{|c|c|c|c|c|}
\hline S. No & Variable & Categories & $\begin{array}{l}\text { Samples } \\
(\mathrm{n}=\mathbf{8 4 7})\end{array}$ & $\begin{array}{c}\text { Percentage } \\
(\%)\end{array}$ \\
\hline \multirow[t]{2}{*}{$\mathbf{1}$} & \multirow[t]{2}{*}{ Gender } & Male & 543 & $64.1 \%$ \\
\hline & & Female & 304 & $35 \cdot 9 \%$ \\
\hline \multirow[t]{2}{*}{2} & \multirow[t]{2}{*}{ Age } & 18-39 years & 446 & $52.6 \%$ \\
\hline & & 40-64years & 401 & $47.4 \%$ \\
\hline \multirow[t]{2}{*}{3} & \multirow[t]{2}{*}{$\begin{array}{l}\text { Educational } \\
\text { Level }\end{array}$} & $\begin{array}{l}\text { Less than } \\
\text { a bachelor } \\
\text { degree }\end{array}$ & 240 & $28.4 \%$ \\
\hline & & $\begin{array}{l}\text { Bachelor's de- } \\
\text { gree or above }\end{array}$ & 607 & $71.6 \%$ \\
\hline \multirow[t]{2}{*}{4} & \multirow[t]{2}{*}{ Occupation } & $\begin{array}{l}\text { Private jobs or } \\
\text { Business }\end{array}$ & 495 & $58.4 \%$ \\
\hline & & $\begin{array}{l}\text { Student or } \\
\text { Government } \\
\text { jobs and PSU }\end{array}$ & 352 & $41.6 \%$ \\
\hline \multirow[t]{2}{*}{5} & \multirow{2}{*}{$\begin{array}{l}\text { Average } \\
\text { monthly } \\
\text { family In- } \\
\text { come (Rs) }\end{array}$} & $\leq 20,000$ & 365 & $43.1 \%$ \\
\hline & & $>20,000$ & 482 & $56.9 \%$ \\
\hline \multirow[t]{2}{*}{6} & \multirow[t]{2}{*}{ Religion } & $\begin{array}{l}\text { Religious Ma- } \\
\text { jority }\end{array}$ & 543 & $64 \cdot 9 \%$ \\
\hline & & $\begin{array}{l}\text { Religious Mi- } \\
\text { norities }\end{array}$ & 304 & $35.1 \%$ \\
\hline
\end{tabular}

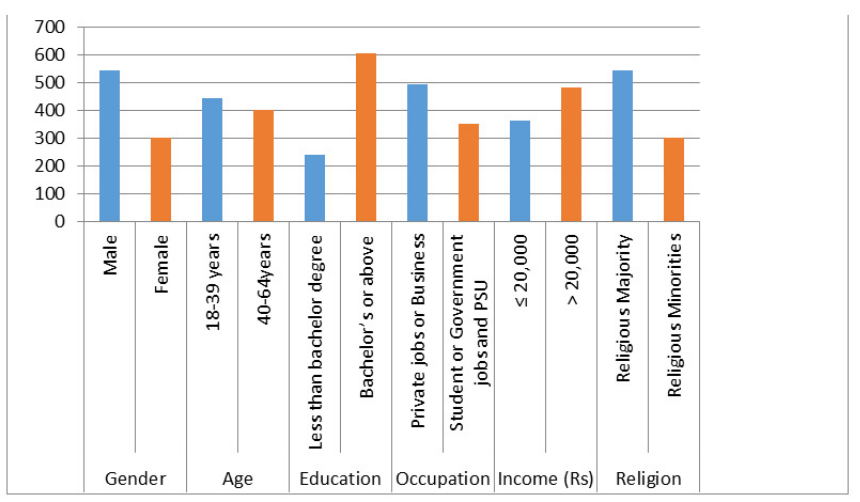

Figure 1: Demography of the participants $(n=847)$.

\section{Knowledge about Corona Virus or COVID-19}

Regarding Knowledge about COVID-19, 543 (64.1\%) participants have some knowledge about COVID-19, whereas only $304(35.9 \%)$ participants have full knowledge about COVID-19, none of the participant was without any knowledge of covid-19 (Table 2).
Table 2: Knowledge about Corona Virus OR COVID-19

\begin{tabular}{clc} 
S. No & $\begin{array}{l}\text { Knowledge about COVID-19 } \\
(\mathbf{n}=847)\end{array}$ & No of Participants \\
\hline 1 & Some knowledge & $543(64.1 \%)$ \\
2 & Full knowledge & $304(35.9 \%)$ \\
\hline
\end{tabular}

\section{Quality of life (WHQOL) and depression anxiety} stress (DASS-21)

Hindi and English version of the questionnaire was used to assess the knowledge of participant about covid-19, Quality of life (WHQOL) and depression, anxiety and stress (DASS21). An unpaired t-test revealed a significant difference in the WHOQOL \& DASS-21 between the male and female participants $(\mathrm{p}=0.0001)$ and age $(\mathrm{p}=0.0001)$ also had a significant effect on these variables. 40-64 years age group in comparison to the youngster (18-39 years) had significantly higher score $\mathrm{p} \leq 0.05$ (Figure 2, 3, Table 3, 4).

The comparison between the participants holding bachelors or above degree and those without bachelor's degree had a significantly higher score than the other groups' $\mathrm{p} 0.0002$ in WHOQOL Scores and $\mathrm{p}=0.0001$ for DASS- 1 score (Figure 4, Table 3, 4).

Occupation also had a significant effect on WHOQOL $(p=0.0001)$ DASS-21(0.0001). In the case of business or private sector job profile people have significantly higher score $\mathrm{p} \leq 0.05$ than other job profiles in the WHOQOL score and DASS-21Score (Figure 6, Table 3, 4). However, it does not differ significantly between the average monthly family income groups $(p>0.05)$. (Figure 5, Table 3,4$)$. The population of the majority religion in comparison to other religions showed a significant difference in WHOQOL $(\mathrm{p}=0.0001)$ and DASS-21 score $(\mathrm{p}=0.0001)$ (Figure 7, Table 3, 4). 61.9\% of the participants reported having psychological problems like depression, anxiety and stress whereas $36.1 \%$ have reported poor Quality of life due to COVID-19 lockdown.

Table 3: Comparison of the World Health Organization Quality of Life (WHOQOL) scale in different demographic groups.

\begin{tabular}{|c|c|c|c|c|c|}
\hline \multirow[t]{2}{*}{ S. No } & \multirow[t]{2}{*}{ Variable } & \multirow[t]{2}{*}{ Categories } & \multicolumn{2}{|c|}{$\begin{array}{c}\text { World Health } \\
\text { Organization } \\
\text { Quality of Life } \\
\text { (WHOQOL) }\end{array}$} & \multirow[t]{2}{*}{$\begin{array}{c}\text { p- } \\
\text { value }\end{array}$} \\
\hline & & & Mean & SD & \\
\hline \multirow[t]{2}{*}{1} & \multirow[t]{2}{*}{ Gender } & Male & 48.9 & 3.8 & \multirow{2}{*}{0.0001} \\
\hline & & Female & 47 & 4.5 & \\
\hline \multirow[t]{2}{*}{2} & \multirow[t]{2}{*}{ Age } & $18-39$ years & 53.1 & 3.4 & \multirow{2}{*}{0.0001} \\
\hline & & 40-64years & 48.2 & 3.8 & \\
\hline \multirow[t]{2}{*}{3} & \multirow{2}{*}{$\begin{array}{l}\text { Educational } \\
\text { Level }\end{array}$} & undergraduate & 50 & 4.8 & \multirow[b]{2}{*}{0.0002} \\
\hline & & $\begin{array}{l}\text { Graduate or } \\
\text { above }\end{array}$ & 48.95 & 3.1 & \\
\hline
\end{tabular}


Table 3: (Continued)

\begin{tabular}{|c|c|c|c|c|c|}
\hline \multirow[t]{2}{*}{ S. No } & \multirow[t]{2}{*}{ Variable } & \multirow[t]{2}{*}{ Categories } & \multicolumn{2}{|c|}{$\begin{array}{c}\text { World Health } \\
\text { Organization } \\
\text { Quality of Life } \\
\text { (WHOQOL) }\end{array}$} & \multirow[t]{2}{*}{$\begin{array}{c}\mathbf{p}^{-} \\
\text {value }\end{array}$} \\
\hline & & & Mean & SD & \\
\hline \multirow[t]{2}{*}{4} & \multirow[t]{2}{*}{ Occupation } & $\begin{array}{l}\text { Private jobs or } \\
\text { Business }\end{array}$ & $47 \cdot 9$ & 3.7 & \\
\hline & & $\begin{array}{l}\text { Student or } \\
\text { Government } \\
\text { jobs and PSU }\end{array}$ & 51 & $3 \cdot 5$ & 0.0001 \\
\hline \multirow[t]{2}{*}{5} & \multirow{2}{*}{$\begin{array}{l}\text { Average } \\
\text { monthly } \\
\text { family in- } \\
\text { come (Rs) }\end{array}$} & $\leq 20,000$ & 48.7 & 4.6 & \\
\hline & & $>20,000$ & 49 & $4 \cdot 4$ & 0.33 \\
\hline \multirow[t]{2}{*}{6} & \multirow[t]{2}{*}{ Religion } & $\begin{array}{l}\text { Religious } \\
\text { Majority }\end{array}$ & 61.2 & 3.2 & \\
\hline & & $\begin{array}{l}\text { Other Reli- } \\
\text { gious Minori- } \\
\text { ties }\end{array}$ & 49.2 & 3.1 & 0.0001 \\
\hline
\end{tabular}

Table 4: Comparison of Depression Anxiety Stress Scales (DASS) in different demographic groups

\begin{tabular}{|c|c|c|c|c|c|}
\hline \multirow[t]{2}{*}{$\begin{array}{l}\text { S. } \\
\text { No }\end{array}$} & \multirow[t]{2}{*}{ Variable } & \multirow[t]{2}{*}{ Categories } & \multicolumn{2}{|c|}{$\begin{array}{l}\text { Depression } \\
\text { Anxiety } \\
\text { Stress Scales } \\
\text { (DASS) }\end{array}$} & \multirow[t]{2}{*}{$\begin{array}{c}\text { p- } \\
\text { value }\end{array}$} \\
\hline & & & Mean & SD & \\
\hline \multirow[t]{2}{*}{1} & \multirow[t]{2}{*}{ Gender } & Male & 39 & 3.4 & \multirow[t]{2}{*}{0.0001} \\
\hline & & Female & 42.1 & 4.2 & \\
\hline \multirow[t]{2}{*}{2} & \multirow[t]{2}{*}{ Age } & 18-39 years & 43 & 3.2 & \multirow[t]{2}{*}{0.0001} \\
\hline & & 40-64years & 46.1 & 3.6 & \\
\hline \multirow[t]{2}{*}{3} & \multirow{2}{*}{$\begin{array}{l}\text { Educational } \\
\text { Level }\end{array}$} & undergraduate & 50.2 & 4.1 & \multirow[t]{2}{*}{0.0001} \\
\hline & & Graduate or above & 42 & 3.2 & \\
\hline \multirow[t]{2}{*}{4} & Occupation & $\begin{array}{l}\text { Private jobs or } \\
\text { Business }\end{array}$ & $37 \cdot 9$ & $3 \cdot 5$ & \multirow[t]{2}{*}{0.0001} \\
\hline & & $\begin{array}{l}\text { Student or Govern- } \\
\text { ment jobs and PSU }\end{array}$ & 42.3 & $3 \cdot 7$ & \\
\hline \multirow[t]{2}{*}{5} & $\begin{array}{l}\text { Average } \\
\text { monthly }\end{array}$ & $\leq 20,000$ & $39 \cdot 5$ & $3 \cdot 9$ & \multirow[t]{2}{*}{0.051} \\
\hline & $\begin{array}{l}\text { family in- } \\
\text { come (Rs) }\end{array}$ & $>20,000$ & 40.1 & 4.8 & \\
\hline \multirow[t]{2}{*}{6} & Religion & Religious Majority & $45 \cdot 5$ & 3.1 & \multirow[t]{2}{*}{0.0001} \\
\hline & & $\begin{array}{l}\text { Other Religious } \\
\text { Minorities }\end{array}$ & 51.2 & 3.2 & \\
\hline
\end{tabular}

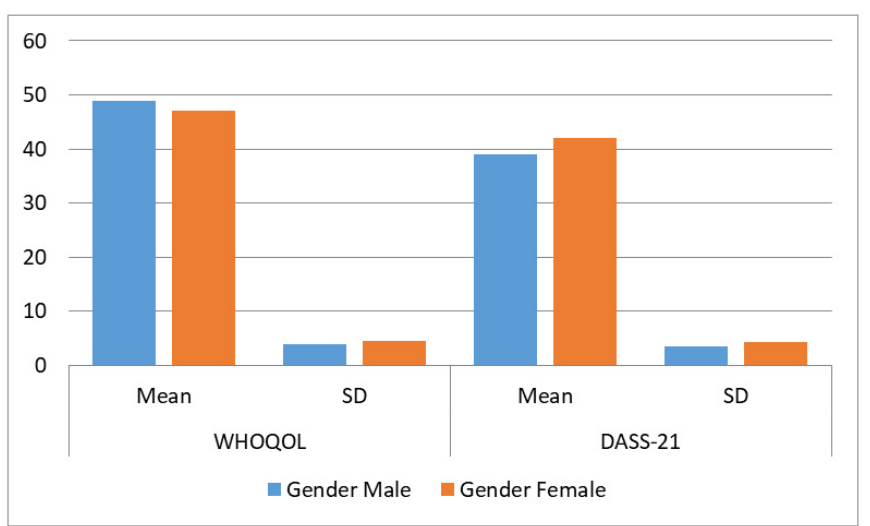

Figure 2: Comparison of WHOQOL*\& DASS-2*in male and female participants.

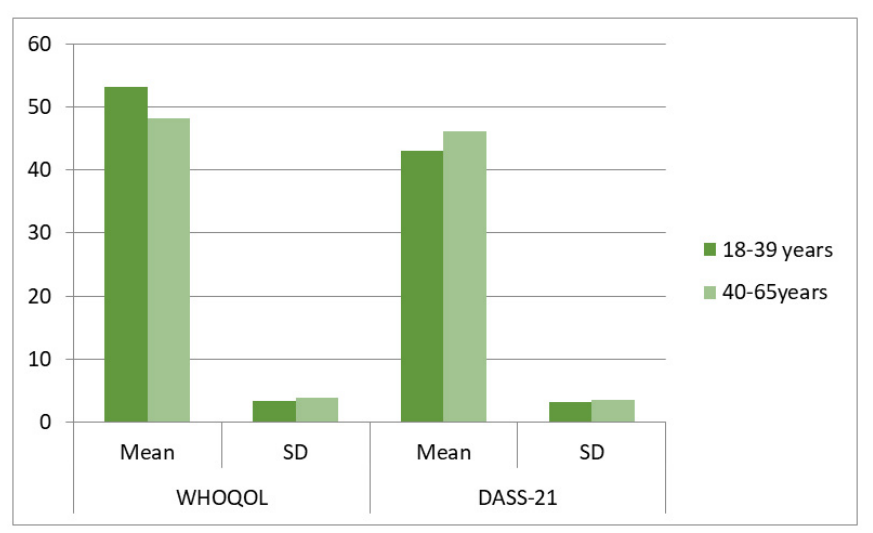

Figure 3: Comparison of WHOQOL"\& DASS-21** with the age of participants in each group.

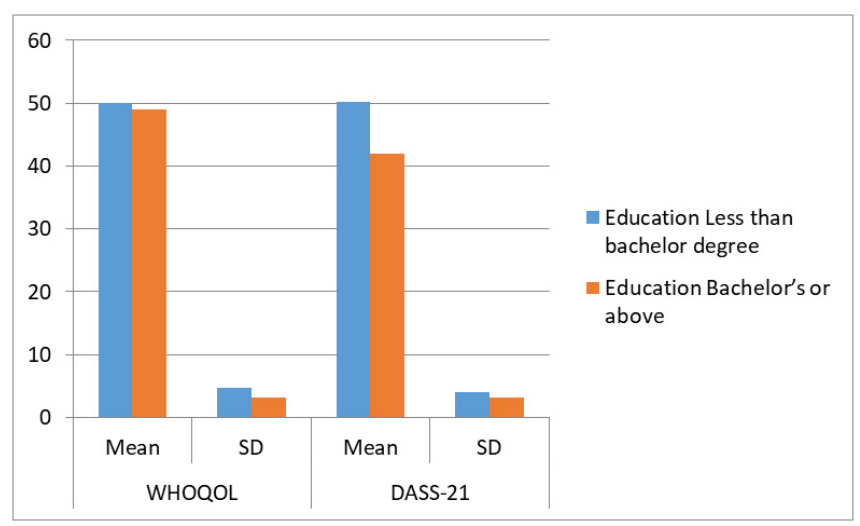

Figure 4: Comparison of WHOQOL*\& DASS-21** with education level of participants in each group. 


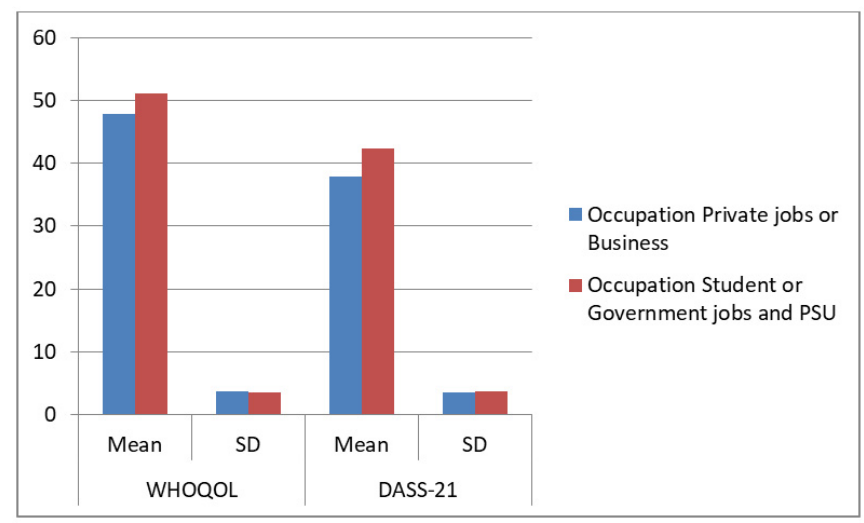

Figure 5: Comparison of WHOQOL ${ }^{*} \&$ DASS-21** with the occupation of participants in each group.

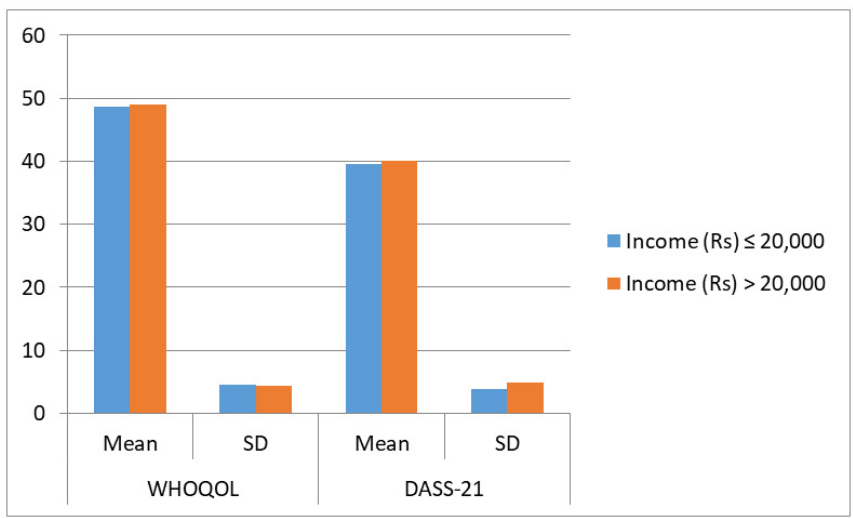

Figure 6: Comparison of WHOQOL $\&$ DASS $-21^{* *}$ with the income of participants in each group.

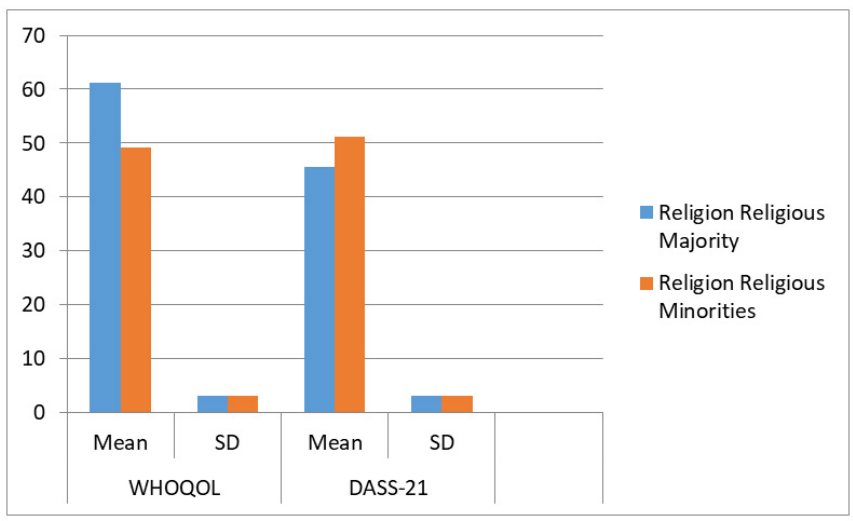

Figure 7: Comparison of WHOQOL ${ }^{*}$ DASS $-21^{* *}$ with the religion of participants in each group.

\section{DISCUSSION}

In this cross-sectional study, we investigated the factors that have influenced the behavioural or psychological issues among the Indian population due to COVID-19 after 45 days of lockdown. Nearly $61.9 \%$ of the participants reported hav- ing Psychological problems like Depression, Anxiety, stress whereas 36.1\% have reported Poor Quality of life due to COVID-19, leading to mental health problems. ${ }^{16}$

It was found that none of the participants was without any knowledge of covid-19, 35.9\% of participants have full knowledge about COVID-19, whereas $64.1 \%$ of participants had some knowledge about COVID-19. (Table 1) This study has shown the huge public awareness and concern related to COVID-19 which also played an important role in the prevention of the spread of this disease. Media have also played an important role in spreading the awareness and control of this pandemic. ${ }^{22}$

The results of this study have shown that Men's score on WHOQOL is slightly higher but their DASS-21 score is also higher than female scores ( $p$ 0.0001) this difference may be due to family responsibilities which are primarily taken care of by men traditionally in Indian. Men are more stressed and anxious but females have a poorer quality of life due to their domestic responsibilities they are fatigued lack adequate sleep, lack of freedom physical and financial security. We found that higher age group people were more prone to have psychological problems (WHQOL, DASS-21 $\mathrm{p}=0.0001$ ) in comparison to other studies. ${ }^{18-20}$ In a similar study in 2009Rubin have also conducted a similar study during the swine flu outbreak in U.K $37.8 \%$ of participants and have reported change in behaviour due to swine flu. ${ }^{21}$ Mihashi conducted a study during the SARS period and he also found that $26.2 \%$ of participants have reported Psychological problems. ${ }^{22}$ Finding of our study have shown slightly more psychological problems $(61.9 \%)$ in comparison to other studies because this is the first time in this century that Indian's were under complete lockdown and the people were not prepared, leading to more mental trauma, Anxiety, Depression, stress. This study was conducted just after the 3 times continuous lockdown in India. Moreover, COVID-19 is still spreading, increasing the number of daily positive cases, rise in mortality due to covid-19, creating more concern.

Regarding educational level lower education participants have shown more behavioural problems in comparison to other groups(WHQOL $\mathrm{p}=0.0002$, DASS-21 $\mathrm{p}=0.0001)$ It may be due to the negative coping style, lack of knowledge to maintain a healthy lifestyle. On comparing job profiles, private-sector employees and self-employed businessmen have a significantly higher score in comparison to other group's (WHQOL, DASS-21 p=0.0001) it may be due to concern of loss of savings, fear of losing jobs, loss in the business and stress of getting infected at the workplace when lockdown opens. Quality of life was slightly better in higher monthly family income group but didn't make any significant difference in the quality of life and depression, anxiety, stress scale(WHQOL, DASS-21 $\mathrm{p} \geq .05$ ) quality of life is a subjective perception and probably the lower income group 
have smaller ambitions and they are satisfied with their lifestyle. Fear of job would be present in both the groups but to maintain a lifestyle without a job might be more difficult in higher-income groups leading to stress and anxiety.

When we compared the results based on religion as India is a multi-religious country, having a huge diversity of other religious minorities. A religious minority were found to have more behavioural issues and hopelessness in comparison to the majority. It may be due to the false belief of association of covid-19 with certain religious groups and places, which creates unnecessary fear in the community leading to have a poor quality of life, depression, anxiety and stress.

We suggest that the government should run effective psychological programs, use mass media, regular counselling sessions, and re-assurance to the poor, needy to provide necessities. Media should also propagate only verified information on covid-19 from the health department of for prevention and treatment to prevent panic and chaos. One of the major problems with the Indian population is also that they are not easily well adaptive to the online working style. They may not be ready to adapt to sudden changes in a short time. May leads to mental pressure and behavioural issues. Therefore future studies will be needed to know the exact cause of their Psychological distress leading to behavioural issues.

Due to its Cross-sectional design, it may not provide strong evidence for causality and assessment. Future research should be needed for longitudinal studies. Results are based on the standard Questionnaires that may have an issue due to self-reporting, Reliability, limited sample size, so it may not represent the entire population. The large sample size must be needed. It may have other variables or confounders this should also be kept in consideration.

\section{CONCLUSION AND FUTURE DIRECTION}

It is suggested that the Indians were living with psychological distress leading to behavioural issues during the COVID-19 pandemic. We also concluded that men have more psychological problems in comparison to the women, lower education and lower socio-economic people are more prone to mental issues leading to behavioural change. Our results emphasize that the government should take necessary preventive measures to control the situation by understanding the ground reality and fulfil the basic needs of the poor and needy.

\section{Disclosure of funding sources}

Not applicable.

\section{Financial disclosure}

The author has no sources of funding or other financial disclosures concerning the above article.

\section{Informed Consent}

Proper Informed Consent was taken from all participants before initiation of the study and Confidentiality was maintained.

\section{Declaration of Competing Interest}

The authors declare that there are no conflicts of interest.

\section{ACKNOWLEDGEMENT}

Authors acknowledge the immense help received from the scholars whose articles are cited and included in references to this manuscript. The authors are also grateful to authors/ editors/publishers of all those articles, journals and books from where the literature for this article has been reviewed and discussed.

\section{Contribution of the Authors}

(1) Conception and design of the study, or acquisition of data, or analysis and interpretation of data,

(2) Drafting the article or revising it critically for important intellectual content,

(3) Proofreading, manuscript writing, and data collection.

\section{REFERENCES}

1. Rajkumar RP. COVID-19 and mental health: A review of the existing literature. Asian J Psychiatr 2020;52:102066.

2. Mak W, Chu CM, Pan PC, Yiu MG, Ho SC, Chan VL. Risk factors for chronic post-traumatic stress disorder (PTSD) in SARS survivors. Gen Hosp Psychiat. 2010;32:590-8.

3. Lau JT, Griffiths S, Choi KC, Tsui HY. Avoidance behaviours and negative psychological responses in the general population in the initial stage of the H1N1 pandemic in Hong Kong. BMC Infect Dis 2010;10:139.

4. Xiang YT, Yu X, Ungvari GS, Correl CU, Chiu HF. Outcomes of SARS survivors in China: not only physical and psychiatric co-morbidities. East Asian Arch Psychiatry. 2014;24:37-8.

5. Bao Y, Sun Y, Meng S, Shi J, Lu L. 2019-nCoV epidemic: address mental health care to empower society. Lancet. $2020 \mathrm{Feb}$ 22;395(10224):e37-e38.

6. Ko CH, Yen CF, Yen JY, Yang MJ. Psychosocial impact among the public of the severe acute respiratory syndrome epidemic in Taiwan. Psychiat Clin Neuros 2006;60:397-403.

7. Ko CH, Yen CF, Yen JY, Yang MJ. Psychosocial impact among the public of the severe acute respiratory syndrome epidemic in Taiwan. Psychiat Clin Neuros 2006; 60:397403.

8. Peng EYC, Lee MB, Tsai ST, Yang CC, Morisky DE, Tsai LT, et al. Population-based post-crisis psychological distress: an example from the SARS outbreak in Taiwan. J Formos Med Assoc 2010;109: 524-32.

9. Yeung NCY, Lau JTF, Choi KC, Griffiths S. Population responses during the pandemic phase of influenza a (H1N1)pdm09 epidemic, Hong Kong. China Emerg Infect Dis. 2017;23:813-5.

10. Taha SA, Matheson K, Anisman H. H1N1 was not all that scary: uncertainty and stressor appraisals predict anxiety related to a coming viral threat. Stress Health 2014;30:149-57. 
11. Shultz JM, Baingana F, Neria Y. The 2014 Ebola outbreak and mental health: current status and recommended response. JAMA 2015;313:567-8.

12. Tang W, Hu T, Hu B, Jin C, Wang G, Xie C, Chen S, Xu J. Prevalence and correlates of PTSD and depressive symptoms one month after the outbreak of the COVID-19 epidemic in a sample of home-quarantined Chinese university students. J Affect Disord 2020 Sep 1;274:1-7.

13. Liang L, Ren H, Cao R, Hu Y, Qin Z, Li C, Mei S. The Effect of COVID-19 on Youth Mental Health. Psychiatr Q. 2020;91(3):841-852.

14. Carr L, Iacoboni M, Dubeau MC, Mazziotta JC, Lenzi GL. Neural mechanisms of empathy in humans: A relay from neural systems for imitation to limbic areas. PNAS 2003;100(9) 5497 5502.

15. Skevington SM, Lotfy M, O'Connell KA. The World Health organization's WHOQOL-BREF quality of life assessment: psychometric properties and results of the international field trial. A report from WHOQOL group. Qual Life Res 2004;13:299-310.

16. Harper R, Doorduyn K, Reeves B, Slater L. Evaluating the outcomes of low vision rehabilitation. Ophthalmic Physiol Opt 1999;19(1):3-11.

17. Lovibond PF, Lovibond SH. The structure of negative emotional states: comparison of the Depression Anxiety Stress Scales (DASS) with the Beck Depression and Anxiety Inventories. Behav Res Ther 1995;33(3):335-43.
18. Lei L, Huang X, Zhang S, Yang J, Yang L, Xu M. Comparison of Prevalence and Associated Factors of Anxiety and Depression Among People Affected by versus People Unaffected by Quarantine During the COVID-19 Epidemic in Southwestern China. Med Sci Monit 2020;26:e924609.

19. Lau JT, Griffiths S, Choi KC, Tsui HY. Avoidance behaviours and negative psychological responses in the general population in the initial stage of the H1N1 pandemic in Hong Kong. BMC Infect Dis.2010;10:139.

20. Corrigan PW, Schmidt A, Bink AB, Nieweglowski K, Al-Khouja MA, Qin S. Changing public stigma with continuum beliefs. J Ment Health 2017;26(5):411-418.

21. Wang Y, Xu J, Lu Y. Associations among trauma exposure, posttraumatic stress disorder, and depression symptoms in adolescent survivors of the 2013 Lushan earthquake. J Affect Disorders 2020;264:407-13.

22. Rubin GJ, Amlôt R, Page L, Wessely S. Public perceptions, anxiety, and behaviour change concerning the swine flu outbreak: a cross-sectional telephone survey. BMJ 2009;339:b2651.

23. Mihashi M, Otsubo Y, Yinjuan X, Nagatomi K, Hoshiko M, Ishitake T. Predictive factors of psychological disorder development during recovery following the SARS outbreak. Health Psychol 2009;28(1):91-100.

24. Hong Y, Kim S. Influence of Presumed Media Influence for Health Prevention: How Mass Media Indirectly Promote Health Prevention Behaviors through Descriptive Norms. Health Commun 2019:1-11. 